\title{
Nitrogen Accumulation in Mycelium of Neurospora crassa
}

\author{
By YOLANDA MORA, GUADALUPE ESPIN, KAETHE WILLMS, \\ AND JAIME MORA \\ Departamento de Biología Molecular, Instituto de Investigaciones Biomédicas, \\ Universidad Nacional Autónoma de México, México 20, D.F.
}

(Received 23 May 1977; revised 29 July 1977)

\begin{abstract}
Mycelium of Neurospora crassa accumulates arginine and glutamine when deprived of an amino acid or pyrimidines, or in the presence of cycloheximide or at the end of exponential growth. A large proportion of the accumulated arginine is sequestered in an osmotically sensitive compartment. Electron microscopy of this fraction shows it consists of mitochondria and electron-dense bodies. Only a small part of the accumulated glutamine was sequestered in this fraction.

Mycelium of this fungus, when deprived of an amino acid, did not catabolize arginine due to a lack of arginase induction. A relationship is proposed between the sequestered arginine, its accumulation, and the lack of induction of arginase. The accumulated glutamine in the cytosol also prevents the catabolism of soluble arginine. Guanosine tetra- and pentaphosphate were not found in the mycelium of $N$. crassa during the deprivation of an amino acid or after cycloheximide treatment.
\end{abstract}

\section{INTRODUCTION}

It has been reported that starvation of histidine and tryptophan mutants of Neurospora crassa results in the derepression of histidine, tryptophan and arginine biosynthetic enzymes. This effect was not due to a lowered intracellular concentration of tryptophan or arginine (Carsiotis \& Jones, 1974; Caŕsiotis, Jones \& Wesseling, 1974). In Saccharomyces cerevisae, it has been found that leaky mutants of amino acid biosynthetic pathways derepress their synthetic enzymes and the appropriate amino acids accumulate (Delforge, Messenguy \& Wiame, 1975). In this paper we report the accumulation of arginine and glutamine in mycelium of $N$. crassa when growth is restricted.

It has been suggested previously that a substantial amount of the arginine found in $N$. crassa growing in minimal medium is localized within an osmotically sensitive compartment that sediments at $15000 \mathrm{~g}$ and which can be separated from mitochondria (Weiss, 1973). We have measured the degree to which accumulated amino acids are osmotically sequestered in such a compartment. We have also attempted to analyse the metabolic relationships between glutamine and arginine that result in the accumulation of these amino acids as nitrogen reservoirs in $N$. crassa.

\section{METHODS}

Organisms. Stocks came either from the Fungal Genetics Stock Center at the Humboldt State University Foundation, Arcata, California, U.S.A., or from the collection of J. Mora. The basic stocks were: wild type 74-A; prol-3 which is unable to synthesize proline and grows in proline, ornithine or arginine (Vogel \& Bonner, 1954); glutamine auxotroph $g l m-I$ which lacks glutamine synthetase; tryptophan auxotroph tryp-2; uridine auxotroph $p y r-3 a$; and $\arg -12^{s}$ which has only $3 \%$ of the ornithine transcarbamylase activity found 
in the wild type (Davis, I962). Escherichia coli mutants CP78 (rel+) and CP79 (rel-), and auxotrophs of leucine, threonine, histidine, arginine and thiamin were kindly provided by Dr F. Bastarrachea (Centro de Investigación y de Estudios Avanzados, Instituto Politécnico Nacional, México).

Culture conditions. Neurospora crassa was grown in minimal medium N (MM) of Vogel (1964) supplemented with $1.5 \%(\mathrm{w} / \mathrm{v})$ sucrose or $2 \%(\mathrm{v} / \mathrm{v})$ glycerol. Conidia harvested from slants of supplemented MM were incubated in $250 \mathrm{ml}$ Erlenmeyer flasks containing $50 \mathrm{ml}$ of the same medium for 3 days in the dark at $29^{\circ} \mathrm{C}$ followed by 2 days in the light at $25^{\circ} \mathrm{C}$. The final culture was inoculated with conidia harvested from the $250 \mathrm{ml}$ flasks by filtration through glass wool, and was grown at $25^{\circ} \mathrm{C}$ in 61 Florence flasks containing 41 medium, aerated with humidified air. The initial absorbance of conidia in the 61 flasks was between 0.05 and 0.1 at $540 \mathrm{~nm}$.

Growth determination. This was carried out as described for $N$. crassa conidia by Espín \& Mora (I978).

Measurement of arginase activity. After growth for $12 \mathrm{~h}$ the mycelium was filtered (Whatman no. 4I filter paper) and thoroughly washed at room temperature with distilled water. Acetone powders were prepared from the mycelium, ground with dry ice and homogenized at $4{ }^{\circ} \mathrm{C}$ with $0.025 \mathrm{M}$-glycine/ $\mathrm{NaOH}$ buffer (pH 9.5) containing $0 . \mathrm{I} \mathrm{M}-\mathrm{KCl}, 0.0 \mathrm{I} \mathrm{M}$-dithiothreitol and $0.125 \mathrm{mM}-\mathrm{MnCl}_{2}$. The homogenates were centrifuged at $4{ }^{\circ} \mathrm{C}$ at $12500 \mathrm{~g}$ for $20 \mathrm{~min}$ and $4 \mathrm{ml}$ of the supernatant was passed through a Sephadex G-25 column $(35 \times 35 \mathrm{~mm})$ equilibrated with homogenization buffer. The void volume fractions which contained the protein peak were pooled and used as the enzyme source. The assay mixture (final volume $1 \cdot 0 \mathrm{ml}$ ) contained 10.5 $\mu \mathrm{mol}$ glycine, $0.28 \mu \mathrm{mol} \mathrm{MnCl}_{2}$ and $10 \mu \mathrm{mol} \mathrm{L}$-[guanidino- $\left.{ }^{14} \mathrm{C}\right]$ arginine (8 to $10 \mathrm{c} . \mathrm{p} . \mathrm{m}$. $\mu \mathrm{mol}^{-1}$ ). The enzyme fraction $(0.3 \mathrm{ml})$ was added to a $10 \mathrm{ml}$ Erlenmeyer flask with a centre well holding a small tube containing $0.25 \mathrm{ml}$ hyamine hydroxide. The flask was covered tightly with a rubber stopper (sleeve type). After $3 \mathrm{~min}$ in a water bath at $25^{\circ} \mathrm{C}$, the reaction was started by the injection of $0.7 \mathrm{ml}$ of assay mixture. The reaction was stopped after 30 or $60 \mathrm{~s}$ by injecting $2 \mathrm{ml} 0.2 \mathrm{M}$-sodium citrate (pH 5.0 ) containing $30 \mathrm{u}$. urease ( $\mathrm{I} \mathrm{u}$. at $30^{\circ} \mathrm{C}$ produces $\mathrm{I} \mathrm{mg}$ ammonia in $5 \mathrm{~min}$ at $\mathrm{pH} 7.0$ from urea). The flasks were then incubated at $37^{\circ} \mathrm{C}$ for $30 \mathrm{~min}$ in a rotary shaker water bath (100 rev. $\mathrm{min}^{-1}$ ) and the reaction was stopped by injecting I $\mathrm{ml} 2 \mathrm{M}-\mathrm{HClO}_{4}$. After a further $45 \mathrm{~min}$ incubation the tubes which contained the hyamine hydroxide were removed and placed in a vial with $15 \mathrm{ml}$ scintillation fluid $[0.4 \%$ (w/v) 2,5-diphenyloxazole and $0.005 \%$ (w/v) I,4-di-2-(5-phenyloxazolyl)benzene in toluene]. The vials were counted in a Nuclear-Chicago scintillation counter ( $85 \%$ efficiency) for a time sufficient to give at least 5000 c.p.m. per sample.

Preparation of soluble extracts for amino acid analysis. Mycelium samples were harvested by filtration (Whatman no. 4I filter paper) and washed with distilled water. Extracts were prepared and analysed for glutamic acid and glutamine as described by Espín \& Mora (1978).

Mycelial arginine was extracted with $2 \mathrm{ml} 5 \%(\mathrm{w} / \mathrm{v})$ trichloroacetic acid, and measured as described by Espín \& Mora (1978).

Samples for amino acid analyses other than glutamic acid and glutamine were obtained by extracting mycelium with I $\%(\mathrm{w} / \mathrm{v})$ picric acid. The extracts were analysed as described by Espín \& Mora (1978).

Incorporation of $\left[{ }^{32} P\right.$ ] orthophosphoric acid into $E$. coli and $N$. crassa. Escherichia coli $\mathrm{CP} 78$ and CP79 were grown according to the method of Cashel (1969), except that ${ }^{32} \mathrm{P}$ at $500 \mu \mathrm{Ci} \mathrm{ml}^{-1}$ was added to the incubation medium. The cells from strain prol-3 of $N$. crassa were grown in MM supplemented with $\mathrm{I} \cdot 5 \%(\mathrm{w} / \mathrm{v})$ sucrose and proline ( $\left.100 \mu \mathrm{g} \mathrm{ml}^{-1}\right)$. After $6 \mathrm{~h}$ incubation the mycelium was harvested by filtration through Millipore filters (type HA, pore size $0.45 \mu \mathrm{m}$ ), washed with distilled water and resuspended in MM containing lower concentrations of phosphate and supplemented with $1 \cdot 5 \%(\mathrm{w} / \mathrm{v})$ sucrose. The specific radioactivity of ${ }^{32} \mathrm{P}$ was raised by lowering the concentration of $\mathrm{KH}_{2} \mathrm{PO}_{4}$ in $\mathrm{MM}$ from the normal $36.74 \mathrm{mM}$ to 10 and $0.02 \mathrm{mM}$. Ten $\mathrm{ml}$ of medium with the two lower phosphate concentrations were incubated at $25^{\circ} \mathrm{C}$ with agitation for $0.5, \mathrm{I}, 2$ and $3 \mathrm{~h}$ with ${ }^{32} \mathrm{P}\left(250 \mu \mathrm{Ci} \mathrm{ml}^{-1}\right)$ in the presence and absence of proline $\left(100 \mu \mathrm{g} \mathrm{ml}^{-1}\right)$. Macromolecular synthesis was restricted by incubating mycelium with cycloheximide $\left(10 \mu \mathrm{g} \mathrm{m}^{-1}\right)$.

Autoradiography of labelled extracts. Acid extraction of ${ }^{32} \mathrm{P}-\mathrm{labelled}$ bacterial and Neurospora cultures was performed as described by Cashel (1969), except that for Neurospora $10 \mathrm{ml}$ of labelled culture was filtered through a Millipore filter, washed with cold distilled water and resuspended in $0.5 \mathrm{ml} 2 \mathrm{M}$-formic

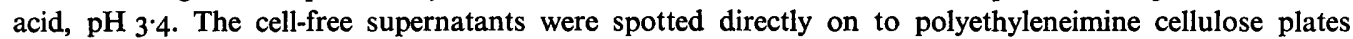
(Cashel, 1969) and subjected to two-dimensional thin-layer chromatography (Cashel, Lazzarini \& Kalbacher, I969). X-ray film was placed over the chromatograms and exposed for $\mathrm{I} 8 \mathrm{~h}$ in the dark. Co-orientation of the films and chromatograms was accomplished with unlabelled standards of nucleotides ( 5 mm), including guanosine tetraphosphate.

Preparation and fractionation of sphaeroplasts. Procedures for the preparation of sphaeroplasts and the fractionation of Neurospora mycelium were as reported by Weiss (I973).

Electron microscopy. Mycelia from strain prol-3 subjected to amino acid deprivation, and the $15000 \mathrm{~g}$ particulate fraction obtained from part of the same culture after the glusulase treatment and homogenization procedure, were fixed at room temperature for $\mathrm{I} \mathrm{h}$ with $2.5 \%(\mathrm{v} / \mathrm{v})$ glutaraldehyde in buffer containing Io $\mathrm{mM}_{\mathrm{M}}-\mathrm{KH}_{2} \mathrm{PO}_{4}, \mathrm{pH} 7 \cdot 5$, and I mm-EDTA. Sorbitol (I $\mathrm{M}$ ) was added to the $15000 \mathrm{~g}$ fraction. The material 


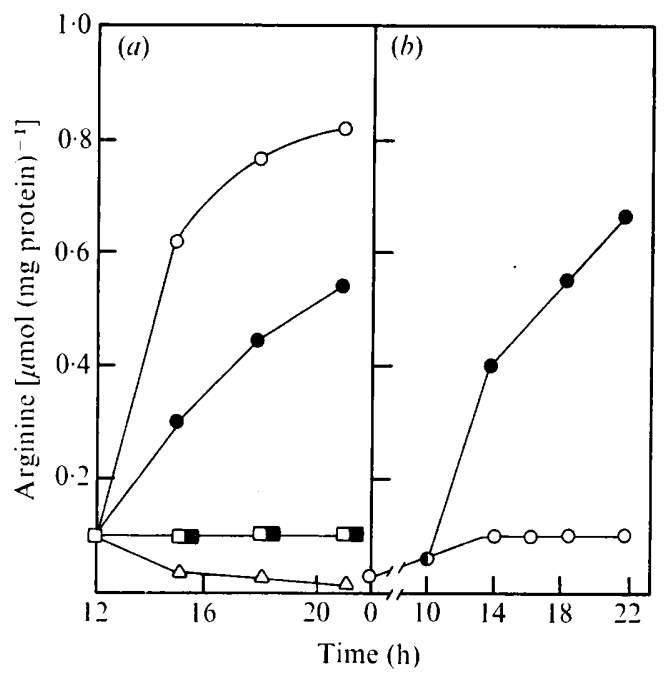

Fig. I. Accumulation of arginine by mycelium of strains prol-3 and 74-A. (a) Conidia from prol-3 were grown in MM plus $\mathrm{I} \cdot 5 \%$ (W/v) sucrose plus proline $\left(100 \mu \mathrm{g} \mathrm{ml}^{-1}\right)$ for $\mathrm{I} 2 \mathrm{~h}$. The culture was then filtered, washed and resuspended in: $O, \mathrm{MM}$ plus sucrose plus cycloheximide (Io $\mu \mathrm{g} \mathrm{ml}^{-1}$ ); - MM plus sucrose; $\square$, MM plus sucrose plus proline; $\square$, MM plus $2 \%$ (v/v) glycerol; $\triangle, \mathbf{M M}$ without $\mathrm{NH}_{4} \mathrm{NO}_{3}$ plus sucrose. (b) Conidia from 74-A were incubated in: $\mathrm{O}, \mathrm{MM}$ plus cycloheximide;, $\mathrm{MM}$ for $10 \mathrm{~h}$ and cycloheximide was then added.

was washed three times with the same buffer, post-fixed with $\mathrm{I} \%(\mathrm{w} / \mathrm{v}) \mathrm{OsO}_{4}$ in $0 \cdot 15 \mathrm{M}-\mathrm{NaH}_{2} \mathrm{PO}_{4}, \mathrm{pH} 7 \cdot 0$, for $\mathrm{I} \mathrm{h}$ at $4{ }^{\circ} \mathrm{C}$, dehydrated in a graded ethanol series and then embedded in Epon (Luft, 1961). Sections were cut with a Porter Blum II ultramicrotome, post-stained in I \% (w/v) uranyl acetate followed by lead citrate (Reynolds, 1966) and examined with a Jeol JEM-100B electron microscope.

Chemicals. All amino acids used were obtained from Calbiochem. Dithiothreitol, urease, glutaminase, bovine serum albumin and nucleotides were obtained from Sigma. L-[Guanidino $\left.{ }^{14} \mathrm{C}\right]$ arginine, L-[U- $\left.{ }^{14} \mathrm{C}\right]-$ glutamine, L-[U-14 $\mathrm{C}]$ glutamic acid, and $\left[{ }^{32} \mathrm{P}\right]$ orthophosphoric acid were purchased from New England Nuclear. L-[Guanidino ${ }^{-14} \mathrm{C}$ ]arginine was further purified by passage over a $\mathrm{I} \cdot 0 \times 5.0 \mathrm{~cm}$ Dowex $50 \mathrm{~W}-\mathrm{X} 8$ column, 200 to 400 mesh. After washing the column with $35 \mathrm{ml} 2 \mathrm{M}-\mathrm{HCl}$, the amino acid was eluted with $35 \mathrm{ml} 4 \mathrm{M}$-HCl. I,4-Di-2-(5-phenyloxazolyl)benzene, 2,5-diphenyloxazole and hyamine hydroxide were obtained from Amersham/Searle Co., Arlington Heights, Illinois, U.S.A. Ninhydrin was purchased from Pierce Chemical Co., Rockford, Illinois, U.S.A. Helix pomatia was obtained from Endo Laboratories. Polyethyleneimine cellulose plates were purchased from Brinkman Instruments, Westbury, New York, U.S.A. X-ray film was from Kodak.

\section{RESULTS}

\section{Mycelial accumulation of amino acids during restriction of protein synthesis}

Mycelium of the prol-3 auxotroph, after growth in proline for $12 \mathrm{~h}$ and transfer to medium without this amino acid, accumulated glutamine and arginine. This accumulation depended on the presence of good carbon and nitrogen sources (Fig. I $a$, Table I). Mycelium, but not conidia, of the wild-type strain 74-A accumulated arginine in the presence of cycloheximide (Fig. I $b$ ). Glutamine was also accumulated under these conditions (Table I). The wild type, in the presence of cycloheximide, accumulated other amino acids although to a lesser extent than glutamine and arginine (Table 2).

The accumulation of glutamine and arginine in mycelium was the result of a biosynthetic process, as indicated by the limited accumulation of arginine in the presence of cycloheximide in a mutant lacking glutamine synthetase $(\mathrm{glm}-\mathrm{I})$ and in one lacking an arginine biosynthetic enzyme $\left(\arg -12^{s}\right)$ (Fig. 2$)$. The latter has only $3 \%$ of the wild-type ornithine transcarbamylase activity and is impaired in the conversion of ornithine to citrulline (Davis, I962). 


\title{
Table I. Mycelial accumulation of glutamine
}

Strains were grown in $\mathrm{MM}$ or $\mathbf{M M}$ plus proline $\left(100 \mu \mathrm{g} \mathrm{ml}^{-1}\right)$ for $12 \mathrm{~h}$ and transferred to $\mathrm{MM}$ with or without cycloheximide $\left(1 \circ \mu \mathrm{g} \mathrm{ml}^{-1}\right)$. Samples for glutamine analysis were taken before and $9 \mathrm{~h}$ after the transfer.

\begin{tabular}{|c|c|c|}
\hline Strain & Condition & $\begin{array}{c}\text { Glutamine } \\
{\left[\mu \mathrm{mol}(\mathrm{mg} \text { protein })^{-1}\right]}\end{array}$ \\
\hline prol-3 & $\begin{array}{l}\text { MM+ proline } \\
\text { 9 h after transfer into: } \\
\text { MM } \\
\text { MM+cycloheximide }\end{array}$ & $\begin{array}{l}0.075 \\
0.550 \\
0.735\end{array}$ \\
\hline $74-\mathrm{A}$ & $\begin{array}{l}\text { MM } \\
9 \text { h after transfer into: } \\
\text { MM + cycloheximide }\end{array}$ & $\begin{array}{l}0.071 \\
0.844\end{array}$ \\
\hline
\end{tabular}

Table 2. Amino acid analysis of wild-type strain 74-A

\begin{abstract}
Mycelium was grown for $\mathrm{I} 2 \mathrm{~h}$ in $\mathrm{MM}$ and cycloheximide $\left(10 \mu \mathrm{g} \mathrm{m}^{-1}\right)$ was then added. Samples for amino acid analysis were taken before and $9 \mathrm{~h}$ after the addition of cycloheximide. Amino acids not shown were below detectable levels. Results are expressed as $\mu \mathrm{mol}(\mathrm{mg} \text { protein })^{-1}$.
\end{abstract}

\begin{tabular}{|c|c|c|c|c|c|}
\hline \multirow[b]{2}{*}{ Amino acid } & \multicolumn{2}{|c|}{ Concentration } & & \multicolumn{2}{|c|}{ Concentration } \\
\hline & $\begin{array}{c}\text { Before } \\
\text { cycloheximide } \\
\text { addition }\end{array}$ & $\begin{array}{l}9 \mathrm{~h} \text { after } \\
\text { cycloheximide } \\
\text { addition }\end{array}$ & Amino acid & $\begin{array}{c}\text { Before } \\
\text { cycloheximide } \\
\text { addition }\end{array}$ & $\begin{array}{c}9 \mathrm{~h} \text { after } \\
\text { cycloheximide } \\
\text { addition }\end{array}$ \\
\hline Aspartic acid & 0.015 & 0.057 & Methionine & 0.007 & 0.011 \\
\hline Threonine & 0.008 & 0.037 & Isoleucine & 0.033 & 0.007 \\
\hline Serine & 0.033 & 0.068 & Leucine & 0.005 & 0.010 \\
\hline Glutamine & $0.06 \mathrm{I}$ & 0.840 & Tyrosine & 0.002 & 0.004 \\
\hline Glutamic acid & 0.025 & 0.109 & Phenylalanine & 0.002 & 0.036 \\
\hline Glycine & 0.025 & 0.017 & Ornithine & 0.004 & 0.066 \\
\hline Alanine & 0.633 & 0.638 & Lysine & 0.013 & 0.020 \\
\hline Cysteine & 0.005 & ND & Histidine & 0.189 & 0.034 \\
\hline Valine & 0.015 & 0.095 & Arginine & 0.084 & 0.593 \\
\hline
\end{tabular}

ND, Not detectable.

Macromolecular synthesis was also limited in mycelium by pyrimidine deprivation. Arginine accumulated in the mycelium of strain pyr-3a when deprived of pyrimidines in the presence or absence of cycloheximide (Fig. 3). Macromolecular synthesis was also restricted at the end of exponential growth. Figure 4 shows the accumulation of glutamine and arginine in strain prol-3 when the growth rate was declining.

The accumulation of arginine by prol-3 mycelium resembled that in conidia, except that in the latter the accumulation occurred only when protein synthesis was partially restricted due to the absence of an amino acid, and not when the cells were deprived of pyrimidines or in the presence of cycloheximide (Espín \& Mora, 1978).

\section{Catabolism of arginine in amino acid-deprived mycelium}

Mycelium of strain prol-3 grown in medium containing proline continued to grow after transfer to medium containing arginine, but not if glutamine was present or if the mycelium had been previously deprived of proline for $3 \mathrm{~h}$ in MM (Fig. 5), a condition under which glutamine accumulated (Table I). The failure of prol-3 to grow in the presence of arginine after incubation in MM alone resulted from the lack of arginase induction by arginine. When arginine was added to mycelium of the mutant strain tryp-2 growing in MM plus indole, arginase induction started immediately and rose $2 \cdot 5$-fold above the basal level after $160 \mathrm{~min}$. However, if the mycelium was first deprived of tryptophan for $3 \mathrm{~h}$ before the addition of arginine, only a limited increase in arginase activity was observed (Fig. 6). 


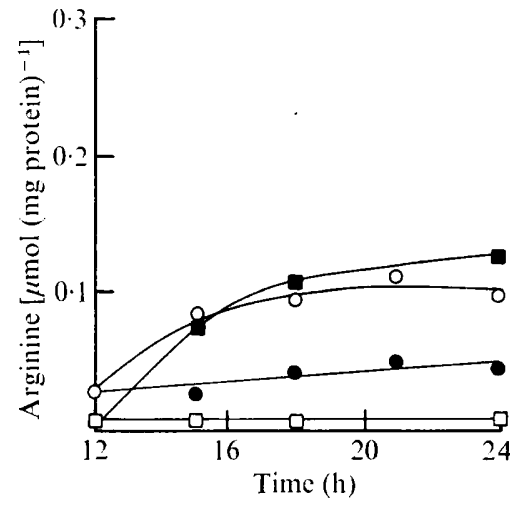

Fig. 2

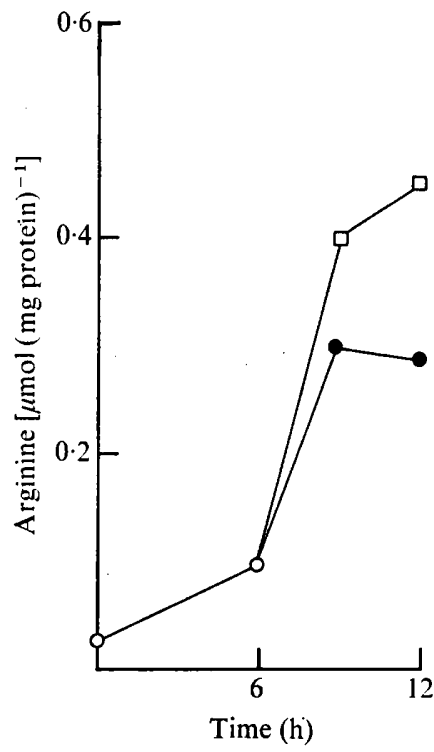

Fig. 3

Fig. 2. Accumulation of arginine by mycelium of strains $g l m-I$ and $\arg -I 2^{8}$. Strain $g l m-I$ was grown in $\mathrm{MM}$ plus glutamine $\left(200 \mu \mathrm{g} \mathrm{ml}^{-1}\right)$ as sole nitrogen source for $12 \mathrm{~h}$. Cycloheximide $\left(10 \mu \mathrm{g} \mathrm{ml}^{-1}\right)$ was added to part of the culture (O) while the rest was transferred to MM (O). Strain $\arg -12^{s}$ was grown in MM for $12 \mathrm{~h}(\square)$ and cycloheximide was then added to part of the culture ( $\boldsymbol{\square}$ ).

Fig. 3. Accumulation of arginine by mycelium of strain pyr-3a. Strain pyr-3a was grown in MM plus uridine $\left(100 \mu \mathrm{g} \mathrm{ml}^{-1}\right)$. After $6 \mathrm{~h}(\mathrm{O})$, the culture was divided, filtered, washed and resuspended in: $O, \mathrm{MM} ; \square, \mathrm{MM}$ plus cycloheximide (Io $\mu \mathrm{g} \mathrm{ml}^{-1}$ ).

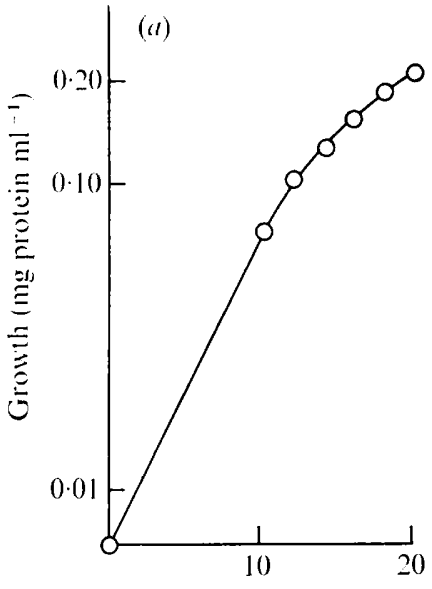

Time (h)

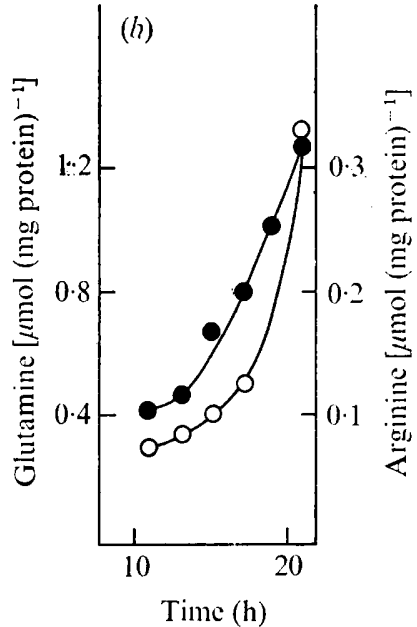

Fig. 4. Accumulation of arginine and glutamine by mycelium of strain prol-3 in the pre-stationary phase of growth. (a) Growth of strain prol-3 in $\mathrm{MM}$ plus proline $\left(100 \mu \mathrm{g} \mathrm{ml}^{-1}\right)$. (b) Pools of glutamine $(\bigcirc)$ and arginine $(O)$ measured at the times indicated in $(a)$. 


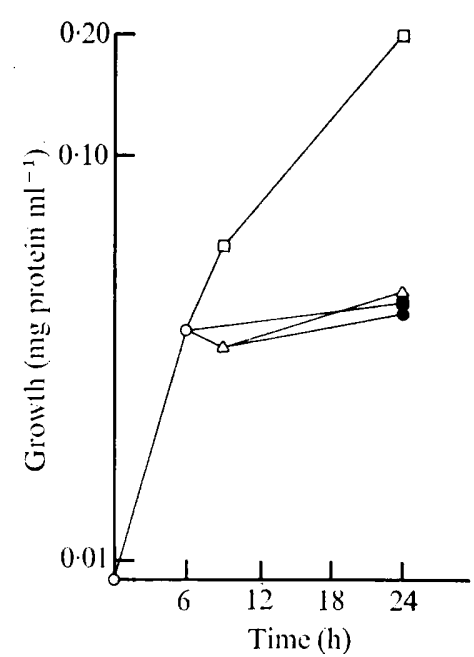

Fig. 5

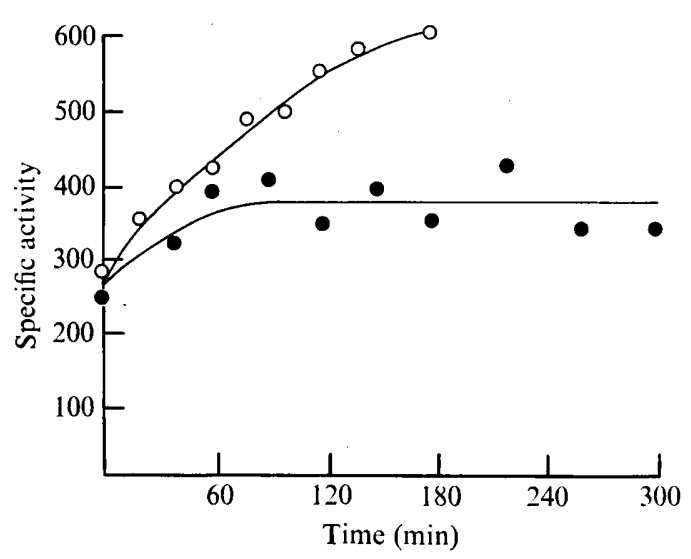

Fig. 6

Fig. 5. Effect of proline deprivation on mycelial growth. Mycelium from strain prol-3 was grown for $6 \mathrm{~h}$ in MM plus proline (100 $\left.\mu \mathrm{g} \mathrm{ml}^{-1}\right)(0)$. The culture was then filtered, washed and resuspended in: $\bigcirc, \mathrm{MM} ; \square, \mathbf{M M}$ plus arginine $\left(100 \mu \mathrm{g} \mathrm{ml}^{-1}\right) ; \square, \mathbf{M M}$ plus arginine plus glutamine $\left(100 \mu \mathrm{g} \mathrm{ml}^{-1}\right) ; \triangle$, MM for $3 \mathrm{~h}$ and then arginine was added.

Fig. 6. Arginase activity in mycelium deprived of an amino acid. Mycelium from strain tryp-2 was grown in MM plus indole $\left(40 \mu \mathrm{g} \mathrm{ml}^{-1}\right)$ for $10 \mathrm{~h}$. Arginine (I $\mu \mathrm{mol} \mathrm{ml}^{-1}$ ) was added to half the culture $(O)$ and the other half was transferred to $\mathrm{MM}$ for $3 \mathrm{~h}$ after which indole plus arginine were added (O). Specific activity is expressed as $\mu \mathrm{mol}$ urea produced $\mathrm{min}^{-1}$ (mg protein) ${ }^{-1}$ at $25^{\circ} \mathrm{C}$.

\section{Intracellular distribution of glutamic acid, glutamine and arginine}

Table 3 shows the distribution of glutamic acid, glutamine and arginine in mycelium of strain prol-3 before and after proline deprivation. In non-deprived mycelium the recovery of arginine and protein from sphaeroplasts was similar (80.55\% and $84 \%$ respectively) to that from whole cells, while there was a loss of glutamic acid $(50.4 \%)$ and of glutamine $(76.5 \%)$ which cannot be accounted for by experimental manipulation. According to the amount of protein and amino acids extracted into the $600 \mathrm{~g}$ supernatant, half of the nondeprived cells were broken by the homogenization procedure after glusulase treatment. Some $7 \%$ [(I/I3.22) $\times 100]$ of the glutamic acid, $27 \%$ of the glutamine and $59 \%$ of the arginine present in the $600 \mathrm{~g}$ supernatant were found in the $15000 \mathrm{~g}$ particulate fraction. When $\mathrm{L}-\left[\mathrm{U}-{ }^{14} \mathrm{C}\right]$ glutamine was added to the $600 \mathrm{~g}$ supernatant and then centrifuged for $20 \mathrm{~min}$ at $\mathrm{I} 5000 \mathrm{~g}$ only $\mathrm{I} \cdot 4 \%$ was bound to the $15000 \mathrm{~g}$ precipitate and the rest was soluble.

A similar distribution of these amino acids was found when mycelium was deprived of a nitrogen source for $\mathrm{I} h$ and then ammonium nitrate was added for $4 \mathrm{~h}$, a condition which enhanced arginine and glutamine accumulation (data not shown). During the preparation of sphaeroplasts, approximately one-third of the protein, glutamic acid and glutamine were lost while the arginine was almost completely recovered. Some $27 \%$ of the protein was solubilized after homogenization of the sphaeroplasts while $10 \%$ of the glutamic acid, $17 \%$ of the glutamine, and $60 \%$ of the arginine present in the $600 \mathrm{~g}$ supernatant was found in the $15000 \mathrm{~g}$ particulate fraction. The amino acids present in the $15000 \mathrm{~g}$ supernatant were found in the soluble fraction after centrifuging for $60 \mathrm{~min}$ at $80000 \mathrm{~g}$. When the $15000 \mathrm{~g}$ pellet was resuspended in I $\mathrm{M}$-sorbitol and centrifuged again at $15000 \mathrm{~g}$, no arginine was found in the supernatant, but when the pellet was resuspended in water, the arginine was completely solubilized. These results indicated that in the osmotically sensitive cells, part of the glutamine and most of the arginine were bound in the cytosol but almost all of the glutamic acid was soluble. The glutamine and the arginine levels in the $15000 \mathrm{~g}$ precipitate were 19- and 4-fold higher, respectively, than in non-deprived cells. 
Table 3. Intracellular distribution of glutamic acid, glutamine and arginine

\begin{tabular}{|c|c|c|c|c|}
\hline Fraction & $\begin{array}{l}\text { Protein } \\
\text { (mg) }\end{array}$ & $\begin{array}{l}\text { Glutamic acid } \\
\qquad(\mu \mathrm{mol})\end{array}$ & $\begin{array}{l}\text { Glutamine } \\
(\mu \mathrm{mol})\end{array}$ & $\begin{array}{c}\text { Arginine } \\
(\mu \mathrm{mol})\end{array}$ \\
\hline \multicolumn{5}{|c|}{ Before proline deprivation } \\
\hline Whole cells & $232 \cdot 89$ & $48 \cdot 40$ & $20 \cdot 24$ & $28 \cdot 00$ \\
\hline Sphaeroplasts & $187 \cdot 61$ & $24 \cdot 00$ & $4 \cdot 76$ & $23 \cdot 52$ \\
\hline $600 \mathrm{~g}$ pellet & 100.51 & $12 \cdot 30$ & I.94 & $12 \cdot 30$ \\
\hline $600 \mathrm{~g}$ supernatant & $95 \cdot 74$ & 14.60 & $2 \cdot 70$ & 10.00 \\
\hline $15000 \mathrm{~g}$ pellet & $22 \cdot 00$ & $\mathbf{I} \cdot \infty$ & 0.51 & $5 \cdot 00$ \\
\hline I $5000 \mathrm{~g}$ supernatant & $62 \cdot 26$ & $12 \cdot 22$ & $1 \cdot 40$ & 3.50 \\
\hline \multicolumn{5}{|l|}{ After proline deprivation } \\
\hline Whole cells & $465 \cdot 50$ & $75 \cdot 32$ & $268 \cdot 52$ & $I 75 \cdot 4 \mathrm{I}$ \\
\hline Sphaeroplasts & $328 \cdot 30$ & $48 \cdot 01$ & 168.07 & 169.45 \\
\hline $600 \mathrm{~g}$ pellet & $225 \cdot 60$ & $37 \cdot 30$ & $122 \cdot 75$ & $104 \cdot 73$ \\
\hline $600 \mathrm{~g}$ supernatant & $71 \cdot 80$ & $16 \cdot 10$ & $49 \cdot 00$ & 36.65 \\
\hline I $5000 \mathrm{~g}$ pellet & $19 \cdot 60$ & $\mathrm{I} \cdot 80$ & $9 \cdot 71$ & 19.60 \\
\hline $15000 \mathrm{~g}$ supernatant & $48 \cdot 85$ & $16 \cdot 00$ & $46 \cdot 20$ & 13.44 \\
\hline
\end{tabular}

Electron micrographs of the $15000 \mathrm{~g}$ particulate fraction (Fig. $7 b$ ) showed it to be composed of membrane-bound organelles: mitochondria, and some electron-dense bodies, both of which also appeared in whole mycelium (Fig. 7.a).

\section{Search for guanosine nucleotides during restriction of macromolecular biosynthesis}

Mycelium was incubated in the presence or absence of proline for up to $3 \mathrm{~h}$. Under these conditions six to nine spots containing ${ }^{32} \mathrm{P}$ were observed below the GTP marker after twodimensional chromatography and autoradiography. None of them, however, co-chromatographed with standards of guanosine tetra- and pentaphosphate (Cashel, 1969) obtained from $E$. coli $\mathrm{CP} 78$ subjected to leucine deprivation. When macromolecular synthesis was completely restricted in $N$. crassa by the presence of cycloheximide, there was no effect upon the presence of the compounds that appeared during amino acid deprivation.

\section{DISCUSSION}

The accumulation of amino acids in mycelium in response to cycloheximide treatment and pyrimidine deprivation differs from that in conidia in that no arginine is accumulated in conidia (Espín \& Mora, 1978). Furthermore, in the presence of cycloheximide amino acid-deprived mycelium accumulated more glutamine and arginine than when only deprived of an amino acid. Although accumulation of certain amino acids occurred in mycelium in the presence of cycloheximide or during uridine deprivation, it is possible that conidia require some nucleic acid and protein synthesis to synthesize the enzymes necessary for the production of glutamine and arginine. We propose that restriction of macromolecular synthesis in mycelium makes available carbon and nitrogen skeletons which, in the presence of the appropriate enzymes, allows the synthesis and accumulation of glutamine and arginine. The results presented in this paper differ from other reports of accumulation of amino acids in Neurospora crassa (Carsiotis \& Jones, 1974; Carsiotis et al., 1974) and Saccharomyces cerevisiae (Schurch, Miozzari \& Hutter, 1974; Delforge et al., 1975) in that the amino nitrogen was accumulated mainly in glutamine and arginine, and that this occurred when the mycelium of $N$. crassa was starved of amino acids or when cycloheximide was added.

It is known that when arginine is added to Neurospora in the exponential phase of 

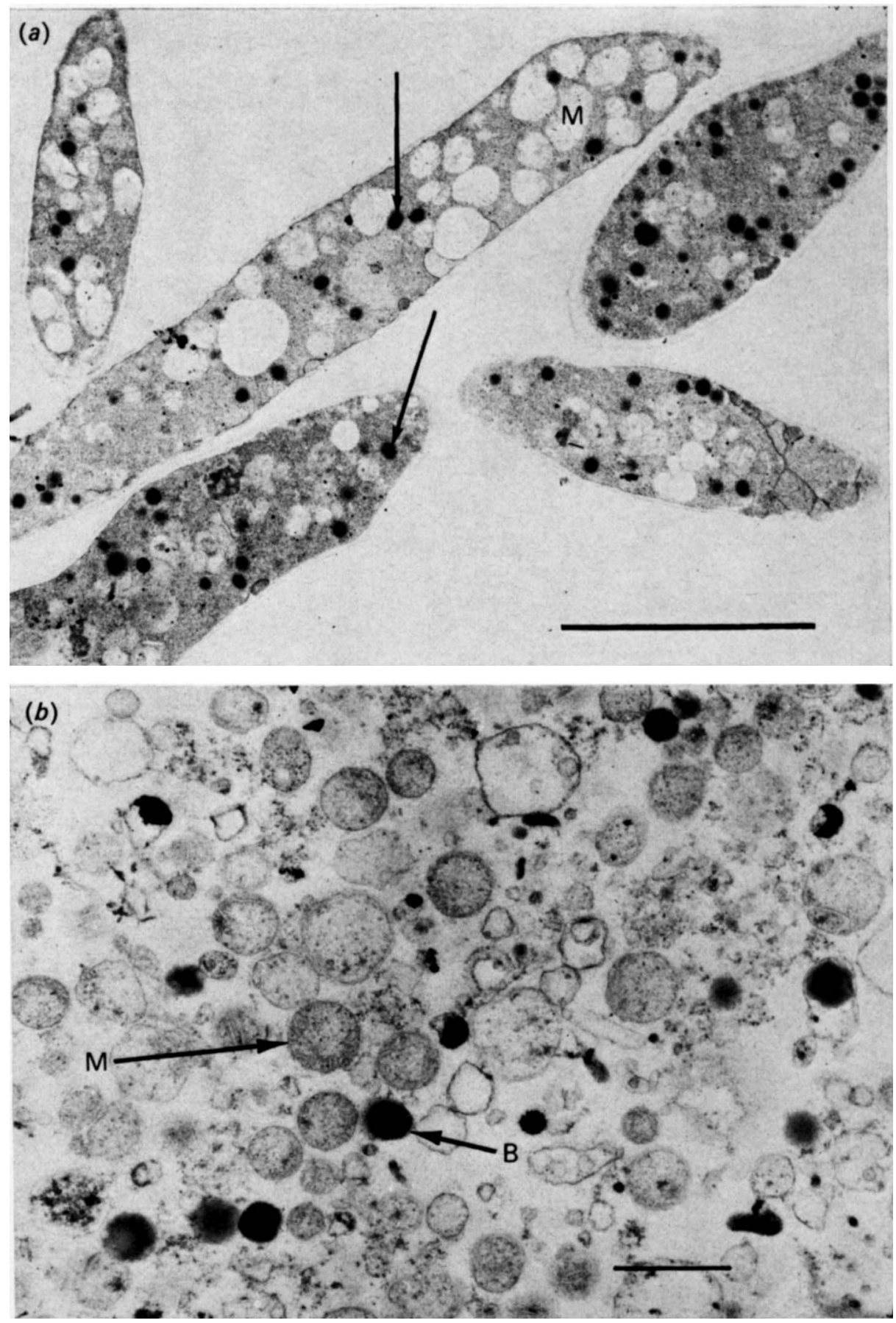

Fig. 7. Electron micrographs. (a) Mycelium of strain prol-3 grown in MM plus proline ( $100 \mu \mathrm{g} \mathrm{ml}^{-1}$ ) for $\mathrm{I} 2 \mathrm{~h}$, transferred to $\mathrm{MM}$ without a nitrogen source for $\mathrm{l} \mathrm{h}$ and then $\mathrm{NH}_{4} \mathrm{NO}_{3}$ $\left(25 \mu \mathrm{mol} \mathrm{ml}^{-1}\right.$ ) was added for $4 \mathrm{~h}$. Note the electron-dense spherical bodies in the cytoplasm (arrowed). Bar marker represents $5 \mu \mathrm{m}$. (b) Pellet from the $15000 \mathrm{~g}$ fraction obtained from the same mycelium. Mitochondria and spherical bodies can be seen, some of which are clearly surrounded by a membrane. Bar marker represents I $\mu \mathrm{m}$. M, mitochondrion; B, electron-dense spherical body. 
growth, arginine synthesis ceases and its catabolism is induced (Castañeda, Martuscelli \& Mora, 1967; Cybis \& Davis, 1975; Davis, Lawless \& Port, 1970). Recently it has been reported that most of the arginine and ornithine synthesized when $N$. crassa is growing exponentially is sequestered in vesicles (Weiss, 1973) and these amino acids are not associated with mitochondria in the $15000 \mathrm{~g}$ pellet. Our results show that, of the arginine recovered after fractionation ( 20 to $30 \%$ ), $60 \%$ was found in the $15000 \mathrm{~g}$ particulate fraction, and also suggest that the dense bodies may contain sequestered arginine, although better techniques must be found to purify this osmotically sensitive fraction for a conclusive demonstration. If particle lysis during sphaeroplast preparation and leakage from intact particles during fractionation are taken into account, it is possible that the amount of sequestered glutamine and arginine is higher. Since the arginine biosynthetic enzyme whose activity is modulated by arginine is soluble (Cybis \& Davis, 1974), our results may explain why endogenous arginine does not inhibit its own synthesis through a feedback mechanism and, hence, is accumulated.

A close metabolic relationship exists between glutamine and arginine, since both have a high nitrogen content and glutamine is the substrate of the arginine biosynthetic pathway as well as the product of the arginine catabolic pathway. The biosynthesis and accumulation of glutamine and arginine are coupled with the inability to catabolize arginine. We suggest that this results from the compartmentation of endogenously synthesized arginine which is thus unable to prevent its own synthesis and induce its own catabolism. We have found that glutamine prevents the catabolism of exogenous arginine by preventing the induction of arginase by arginine (Vaca \& Mora, 1977). As demonstrated in this paper, endogenously synthesized arginine is not catabolized nor is arginase induced by exogenous arginine after the mycelia have been deprived of an amino acid, possibly as a result of the accumulation of glutamine. This metabolic mechanism also prevents the catabolism of arginine present in the cytosol and avoids a futile glutamine-arginine synthetic-catabolic cycle.

Alberghina and co-workers reported the absence of guanosine tetraphosphate during a shift-down transition of growth which restricts RNA synthesis in $N$. crassa (Alberghina et al., 1973). These investigators used a phosphate label of specific activity 25 times below that used here. They found five spots which incorporated ${ }^{32} \mathrm{P}$ and appeared under the GTP marker and suggested that these may be polyphosphates (Harold, 1962). Buckel \& Bock (1973) also reported the absence of guanosine tetra- and pentaphosphate during amino acid deprivation in $N$. crassa. There is only one report of the possible presence of guanosine tetraphosphate in N. crassa (DeCarlo \& Somberg, 1974).

We wish to thank Dr Rafael Palacios for his criticism throughout this work and Dr Marcella Vogt for helping us with the manuscript. This research was supported in part by CONACYT (Consejo Nacional de Ciencia y Tecnología, México).

\section{REFERENCES}

Alberghina, F. M., Schiaffonati, L., Zardi, L. \& StURANI, E. (I973). Lack of guanosine tetraphosphate accumulation during inhibition of RNA synthesis of Neurospora crassa. Biochimica et biophysica acta 312, 435-439.

BuCKel, P. \& Bock, A. (1973). Lack of accumulation of unusual guanosine nucleotides upon amino acid starvation of two eukaryotic organisms. Biochimica et biophysica acta 324, 184-187.

CARsiotis, M. \& Jones, R. F. (I974). Cross-pathway regulation: tryptophan-mediated control of histidine and arginine biosynthetic enzymes in Neurospora crassa. Journal of Bacteriology 119, 889-892.
Carsiotis, M., Jones, R. F. \& Wesseling, A. C. (1974). Cross-pathway regulation: histidinemediated control of histidine, tryptophan, and arginine biosynthetic enzymes in Neurospora crassa. Journal of Bacteriology 1 19, 893-898.

Cashel, M. (1969). The control of ribonucleic acid synthesis in Escherichia coli. IV. Relevance of unusual phosphorylated compounds from amino acid starved stringent strains. Journal of Biological Chemistry 244, 3I 33-3I4I.

Cashel, M., Lazzarini, R. A. \& Kalbacher, B. (1969). An improved method for thin layer chromatography of nucleotide mixtures con- 
taining ${ }^{32}$ P-labeled orthophosphate. Journal of Chromatography 40, 103-I09.

Castañeda, M., Martuscelli, J. \& Mora, J. (1967). The catabolism of L-arginine by Neurospora crassa. Biochimica et biophysica acta I4r, 276-282.

CybIS, J. J. \& DavIs, R. H. (1974). Acetylglutamate kinase: a feedback-sensitive enzyme of arginine biosynthesis in Neurospora. Biochemical and Biophysical Research Communications 60, 629-634.

CrBIS, J. J. \& DAvIS, R. H. (I975). Organization and control in the arginine biosynthetic pathway of Neurospora. Journal of Bacteriology 123, 196202.

DAvis, R. H. (1962). A mutant form of ornithine transcarbamylase found in a strain of Neurospora carrying a pyrimidine-proline suppressor gene. Archives of Biochemistry and Biophysics 97, 185I9I.

Davis, R. H., Lawless, M. B. \& PoRT, L. A. (1970). Arginaseless Neurospora: genetics, physiology, and polyamine synthesis. Journal of Bacteriology I02, 299-305.

DeCarlo, R. R. \& Somberg, E. W. (1974). The effect of essential amino acid deprivation on macromolecular synthesis and nucleotide pool sizes in Neurospora crassa. Archives of Biochemistry and Biophysics 165, $20 \mathrm{I}-2 \mathrm{r} 2$.

Delforge, J., Messenguy, F. \& Wiame, J. M. (I975). The regulation of arginine biosynthesis in Saccharomyces cerevisiae. The specificity of arg $\mathrm{R}^{-}$mutations and the general control of amino acid biosynthesis. European Journal of Biochemistry 57, 23I-239.

Espín, G. \& MORA, J. (1978). Effect of the deprivation of amino acids on conidia of Neurospora crassa. Journal of General Microbiology ro4, 233240.

HaRold, F. M. (I962). Depletion and replenishment of the inorganic polyphosphate pool in Neurospora crassa. Journal of Bacteriology $\mathbf{8 3}$, I047-1057.

LUFT, J. H. (196I). Improvements in epoxy resin embedding methods. Journal of Biophysical and Biochemical Cytology 9, 409-4I4.

REYNolds, E. A. (1966). The use of lead citrate at high $\mathrm{pH}$ as an electron-opaque stain in electron microscopy. Journal of Cell Biology I7, 208-2 I 2.

Schurch, A., Miozzari, J. \& Hutter, R. (I974). Regulation of tryptophan biosynthesis in Saccharomyces cerevisiae: mode of action of 5-methyl tryptophan sensitive mutants. Journal of Bacteriology 227, I I 3 I-I 140.

VACA, G. \& MORA, J. (1977). Nitrogen regulation of arginase in Neurospora crassa. Journal of Bacteriology 131, 719-725.

VoGeL, H. J. (1964). Distribution of lysine pathways among fungi: evolutionary implications. American Naturalist $98,435-446$.

Vogel, H. J. \& BonNer, D. M., (1954). On the glutamate-proline-ornithine inter-relation in Neurospora crassa. Proceedings of the National Academy of Sciences of the United States of America 40, 688-694.

WeISS, R. L. (I973). Intracellular localization of ornithine and arginine pools in Neurospora. Journal of Biological Chemistry 248, 5409-54I 3.

WeISS, R. L. \& DAvis, R. H. (I973). Intracellular localization of enzymes of arginine metabolism in Neurospora. Journal of Biological Chemistry 248, 5403-5408. 